\title{
Epidemiologic and clinical parameters of West Nile virus infections in humans: a scoping review
}

Man Wah Yeung, Emily Shing®, Mark Nelder and Beate Sander

\begin{abstract}
Background: Clinical syndromes associated with West Nile virus (WNV) infection range from fever to neuroinvasive disease. Understanding WNV epidemiology and disease history is important for guiding patient care and healthcare decision-making. The objective of this review was to characterize the existing body of peer-reviewed and surveillance literature on WNV syndromes and summarize epidemiologic and clinical parameters.
\end{abstract}

Methods: We followed scoping review methodology described by the Joanna Briggs Institute. Terms related to WNV epidemiology, hospitalization, and surveillance were searched in four bibliographic databases (MEDLINE, EMBASE, Scopus, and CINAHL) for literature published from January 1999 to December 2015.

Results: In total, 2334 non-duplicated titles and abstracts were screened; 92 primary studies were included in the review. Publications included one randomized controlled trial and 91 observational studies. Sample sizes ranged from under 25 patients $(n=19)$ to over 400 patients $(n=28)$. Eight studies were from Canada, seven from Israel, and the remaining $(n=77)$ from the United States. $N=17$ studies were classified as outbreak case investigations following epidemics; $n=37$ with results of regional/national surveillance and monitoring programs.

Mean patient ages were $>40$ years old; three studies (3\%) focused on the pediatric population. Patients with encephalitis fared worse than patients with meningitis and fever, considering hospitalization, length of stay, discharge, recovery, and case-fatality. Several studies examined risk factors; however, age was the only risk factor for neuroinvasive disease/death consistently identified. Overall, patients with acute flaccid paralysis or encephalitis fared worse than patients with meningitis and West Nile fever in terms of hospitalization and mortality. Among the included studies, proportion hospitalized, length of stay, proportion discharged home and case-fatality ranged considerably.

Conclusion: Our review highlights the heterogeneity among reporting clinical WNV syndromes and epidemiologic parameters of WNV-related illness. Presently, there is potential for further synthesis of the risk factors of WNV-illness and mortality; undertaking further analysis through a systematic review and meta-analysis may benefit our understanding of risk factors for emerging mosquito-borne diseases. Future research on the burden of WNV can build on existing evidence summarized in this review, not only to support our understanding of endemic WNV, but also to strengthen research on emerging arboviruses with similar clinical manifestations.

Keywords: West Nile virus, Epidemiologic parameters, Neurologic syndromes, Scoping review

\footnotetext{
* Correspondence: beate.sander@theta.utoronto.ca

Public Health Ontario, Toronto, Canada, Institute for Clinical Evaluative

Sciences, Toronto, Canada, Institute of Health Policy, Management and

Evaluation, University of Toronto, Toronto, Canada
}

(C) Queen's Printer for Ontario. 2017 Open Access This article is distributed under the terms of the Creative Commons 4.0 Attribution License (http://creativecommons.org/licenses/by/4.0/), which permits unrestricted use, distribution, and reproduction in any medium, provided you give appropriate credit to the original author(s) and the source, provide a link to the Creative Commons license, and indicate if changes were made. The Creative Commons Public Domain Dedication waiver (http://creativecommons.org/publicdomain/zero/1.0/) applies to the data made available in this article, unless otherwise stated. 


\section{Background}

Since its introduction in 1999, West Nile virus (WNV) has caused seasonal epidemics and epizootics throughout North America. With warming temperatures and changing precipitation patterns, the geographic range for WNV mosquito vectors continues to expand [1]. Disease epidemiology varies by geographic locale and epidemic season [2]. Syndromes range from mild West Nile fever to severe or fatal neuroinvasive disease, including acute flaccid paralysis, meningoencephalitis, encephalitis, meningitis, or some combination of these.

Disease burden and economic costs over the short and long-term are considered to be significant from complications and hospitalizations that can result in death [3-6]. High-quality data on hospitalization and mortality are important for guiding patient care and healthcare decision-making. A recent systematic review examined the long-term physical, cognitive, and functional sequelae of West Nile virus [7]; however, hospitalization and recovery characteristics and risk factors for WNVrelated mortality were beyond its scope. The objective of the present scoping review is to characterize the literature on WNV and summarize the epidemiologic and clinical parameters related to WNV infections in North America.

We aim to synthesize the existing evidence and identify potential research gaps for future primary studies and systematic reviews. The objectives and inclusion criteria were specified in advance and documented as part of a larger study on the cost-effectiveness of WNV intervention strategies (Canadian Institutes of Health Research Operating Grant, MOP 133571).

\section{Methods}

\section{Guidelines}

We followed methodology as described by the Joanna Briggs Institute for conducting scoping reviews [8]. Scoping review methodology was selected over a systematic review for three key reasons. First, unlike systematic reviews, scoping reviews are intended to provide an overview of the existing evidence base regardless of quality, emphasizing the value in extracting information from non-traditional study types (e.g., surveillance and case series), not only to summarize the content of the research, but also paying attention to how the data was collected. Thus, an assessment of methodological quality of the studies reviewed is beyond the scope of this type of review. Second, the scoping review offers a suitable template to summarize the wide range of WNV illness clinical syndromes, including areas where data on specific syndromes may be missing. Finally, the iterative process of defining project objectives is a strength of scoping reviews over systematic review methodology that requires a fixed research objective. We leveraged these features of the scoping review to systematically summarize the epidemiologic and clinical knowledge of WNV illness and provide recommendations for future research.

\section{Identifying relevant studies}

We searched the following electronic databases: MEDLINE (January 1, 1999 to December 31, 2015), EMBASE (January 1, 1999 to 2015 Week 52), CINAHL Plus with Full Text (January 1, 1999 to December 31, 2015) and Scopus (January 1, 1999 to December 31, 2015). A librarian developed the search strategies using the concepts of WNV, epidemiology, surveillance, hospitalization and mortality (Additional file 1: Appendix I).

\section{Inclusion/exclusion criteria}

We included primary studies of human WNV infections and excluded case reports and non-English studies. Inclusion of studies was also determined by considering geographic and temporal factors, in combination. Genetic relatedness of WNV strains in the Israel/American cluster of Lineage 1 (clade 1a) isolated from outbreaks in New York in 1999 to strains isolated in Israel and Hungary, strongly supports the hypothesis of highly pathogenic, neurovirulent WNV Lineage 1 strains from this cluster introduced to North America in 1999 from Hungary, by way of Israel [9-11]. Outbreaks in Europe around the Mediterranean basin belonging to the Mediterranean/Kenyan cluster of Lineage 1 caused moderate pathogenicity in horses and humans with limited, if any, pathogenicity in birds [10]. This is in contrast to high rates of disease and mortality among birds, horses, and humans caused by infections from the Israel/ American cluster. Thus, given our current understanding of WNV phylogeny and pathogenicity, we included only studies that described the clinical and epidemiologic parameters of the Israel/American cluster of WNV Lineage 1 affecting North America and Israel, published after 1999.

The distinct Lineage 2 was historically limited to subSaharan Africa and detected in Europe in 2004 in birds and humans. It was not until 2010 that infections due to WNV Lineage 2 strains were attributed to neurologic disease [12]. Therefore, to maintain geographic and temporal consistency of studies describing neuroinvasive WNV, we excluded any studies that were conducted on populations that were highly likely to be infected by WNV Lineage 2 - that is, countries outside of North America or Israel.

Two independent reviewers (ES, MY) screened titles and abstracts, followed by full-text reviews; we resolved discrepancies in study selection by consensus.

\section{Charting data}

One reviewer (MY or ES) extracted the following epidemiologic and clinical data: 
(i) Index hospitalization length of stay (LOS)

(ii) Proportion discharged from hospital

(iii)Proportion who fully recover

(iv) Mortality

(v) Risk factors associated with developing neuroinvasive disease

(vi)Risk factors associated with mortality

We qualitatively synthesized the data, stratifying by WNV syndromes: acute flaccid paralysis (AFP), meningoencephalitis (WNME), encephalitis (WNE), meningitis (WNM) and West Nile fever (WNF). AFP involves asymmetric paralysis of limbs with or without brainstem involvement and respiratory failure. WNME involves inflammation of the brain and the surrounding meninges. WNE involves inflammation of the brain only whereas WNM involves the meninges and the spinal cord.

Mortality data were stratified as in-hospital, acute or long-term. Acute mortality captured the period postinfection with often no distinction between deaths that occurred during hospitalization and deaths that occurred during convalescence after hospitalization. Long-term mortality captured deaths that occurred years after illness onset.

\section{Results}

We screened 2334 non-duplicated titles and abstracts and included 92 primary studies in the review (Fig. 1). Table 1 shows the summary of study characteristics (Additional file 2: Table S1 Characteristics of included studies $(n=92)) .2169$ irrelevant records were excluded after title and abstract screening.
Eight studies were from Canada [13-20], seven from Israel [21-27] and the remaining $(n=77)$ from the United States (including Texas $n=12$, Colorado $n=10$, Louisiana $n=5$, Illinois $n=5$, New York $n=4)$. Mean patient ages were mostly $>40$ years old, three studies (3\%) focused on the pediatric population. Sample sizes ranged from under 25 patients $(n=19)$ to over 400 patients $(n=28)$.

Figure 2 shows the number of publications were greatest in 2004 $(n=12)$ and $2005(n=11)$, following early WNV outbreaks and spread in North America (2000-2003). Publications included one randomized controlled trial and 91 observational studies including cohort, case-control, cross-sectional, and case series ( $>1$ patient per syndrome) study types. Unique to the dependency of WNV mosquito vectors on climatic and seasonal variability in North America, we also classified $n=17$ studies as outbreak case investigations following epidemics; $n=37$ with results of regional/ national surveillance and monitoring programs, typically published as an annual summary in the CDC Morbidity and Mortality Weekly Report ( $n=15,2000-2014)$.

The summary findings below are stratified by WNV syndrome. Since few studies $(n=2)[28,29]$ reported outcomes specific to WNME (not in combination with other syndromes), it was grouped with WNE due of their clinical similarities [30].

\section{Hospitalization and recovery}

Fifty-three studies were summarized for data on index hospitalization (Fig. 3; Additional file 1: Table S2). Studies reported the proportion of patients hospitalized,

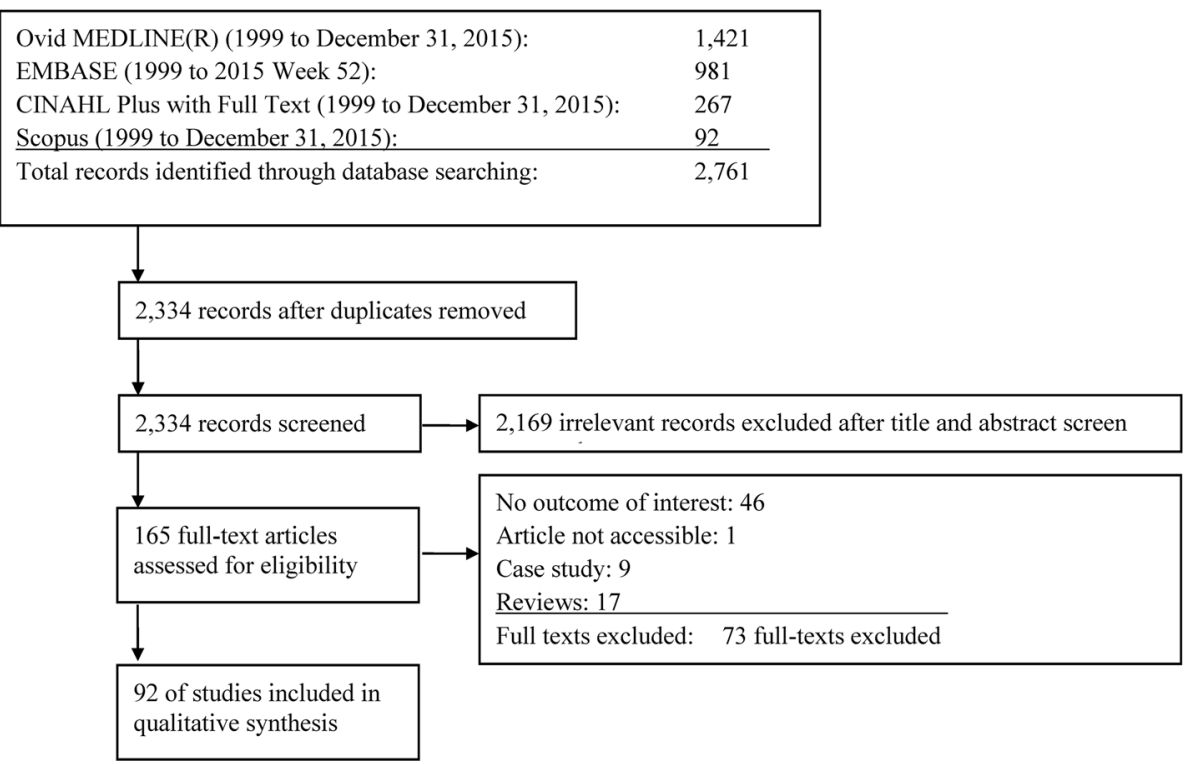

Fig. 1 Flow diagram of studies through the scoping review process 
Table 1 Summary of study characteristics $(n=92)$

\begin{tabular}{|c|c|}
\hline Study characteristic & $\mathrm{N}(\%)$ \\
\hline \multicolumn{2}{|l|}{ Country $^{a}$} \\
\hline United States & $77(84)$ \\
\hline Canada & $8(9)$ \\
\hline Israel & $7(8)$ \\
\hline \multicolumn{2}{|l|}{ Case ascertainment period } \\
\hline$<6$ months & $28(30)$ \\
\hline 6-12 months & $41(45)$ \\
\hline$>12$ months & $23(25)$ \\
\hline \multicolumn{2}{|l|}{ Sample size } \\
\hline$<25$ & $19(21)$ \\
\hline $25-100$ & $22(24)$ \\
\hline $100-400$ & $23(25)$ \\
\hline$>400$ & $28(30)$ \\
\hline \multicolumn{2}{|l|}{ Study design ${ }^{b}$} \\
\hline Experimental design & $1(1)$ \\
\hline Randomized controlled trial & $1(1)$ \\
\hline Observational design & $91(99)$ \\
\hline Surveillance and monitoring program & $37(40)$ \\
\hline Case series & $30(33)$ \\
\hline Outbreak investigation & $17(18)$ \\
\hline Cohort & $4(4)$ \\
\hline Case-control & $2(2)$ \\
\hline Cross-sectional & $1(1)$ \\
\hline
\end{tabular}

${ }^{a}$ Only studies in US, Canada, and Israel were included

${ }^{\mathrm{b}}$ Percentages may not add to $100 \%$ due to rounding

LOS, proportion discharged home and proportion fully recovered. Hospital discharges back home provided a proxy for recovery, as opposed to other discharge dispositions (e.g., rehabilitation facility, long-term care facility, death). The definition of full recovery varied across studies. Some defined recovery as not requiring additional health services, others as returning to baseline or near baseline levels physically, cognitively and/or functionally.

\section{WNND hospitalization}

Of the WNND syndromes, WNM accounted for the lowest proportion of hospitalizations - $81 \%$ of reported WNM cases were hospitalized in the United States compared to $86 \%$ of WNE cases and $82 \%$ of AFP cases [31]. The maximum mean LOS among patients with WNND was 19 days [32]. Specifically, patients with AFP had a mean LOS of 11-68 days [18, 33] and patients with WNE had a mean LOS of 8-25 days [13, 34]. WNM was associated with short LOS, mainly ranging 4-5 days [34-36] and up to 12 days during the first North American outbreak (New York City 1999) [37].

\section{WNF hospitalization}

Overall, patients with WNF had proportionally fewer hospitalizations than those with WNND. This ranged from $8 \%$ of reported WNF cases being hospitalized in North Dakota's outbreak [38] to 38\% in Illinois's first human outbreak in 2002 [34]. When stratified by age, WNF cases aged 65 and older had relatively more hospitalizations (78\%) compared to patients under 45 years (3\%) [39]. The maximum mean LOS among patients with WNF was shorter than that of patients with WNND (7 versus 20 days for WNE cases; 10 days for WNM cases) [40].

\section{WNND recovery}

Patients with AFP fared worst among WNND patients over the period studied, with only $7 \%$ regaining baseline muscle strength based on manual muscle testing [41]. In comparison, 63\% with WNE and 100\% with WNM returned to normal functioning [42]. In terms of discharges from index hospitalization, the proportion of patients with AFP discharged home ranged from $0 \%$ (where all patients required long-term care facilities) [42] to 45\% [43]. Among patients with WNE, 20-33\% were discharged home [44-46]. One outlier was in a case series where $80 \%$ were discharged home, but patients required oral feedings and were at a modified independent level [29]. Patients with WNM had the highest home dispositions (77-90\%) [45, 46] and reached up to $100 \%$ among children [36].

\section{WNF recovery}

Between $40 \%$ [47] to $69 \%$ [21] returned to baseline levels of function as defined by basic activity of daily living scores and absence of persistent symptoms, respectively. One study on Colorado's 2003 outbreak reported home discharges from index hospitalization (68\%) where the median age of patients with WNF was 59 years [44].

\section{Mortality}

Sixty-one studies were summarized for in-hospital mortality, acute mortality and long-term mortality (Fig. 4; Additional file 1: Table S3). Most studies examined acute mortality $(n=41)$, while four studies examined longterm mortality (two to 10 years) [23, 48-51]. Five studies differentiated deaths attributable to WNV [14, 52-55], while the remaining examined all-cause mortality. Most presented case fatalities calculated as the number of deaths as a proportion of the number of WNV cases. Few presented survival models, namely Kaplan-Meier curves [23, 48-51]. 


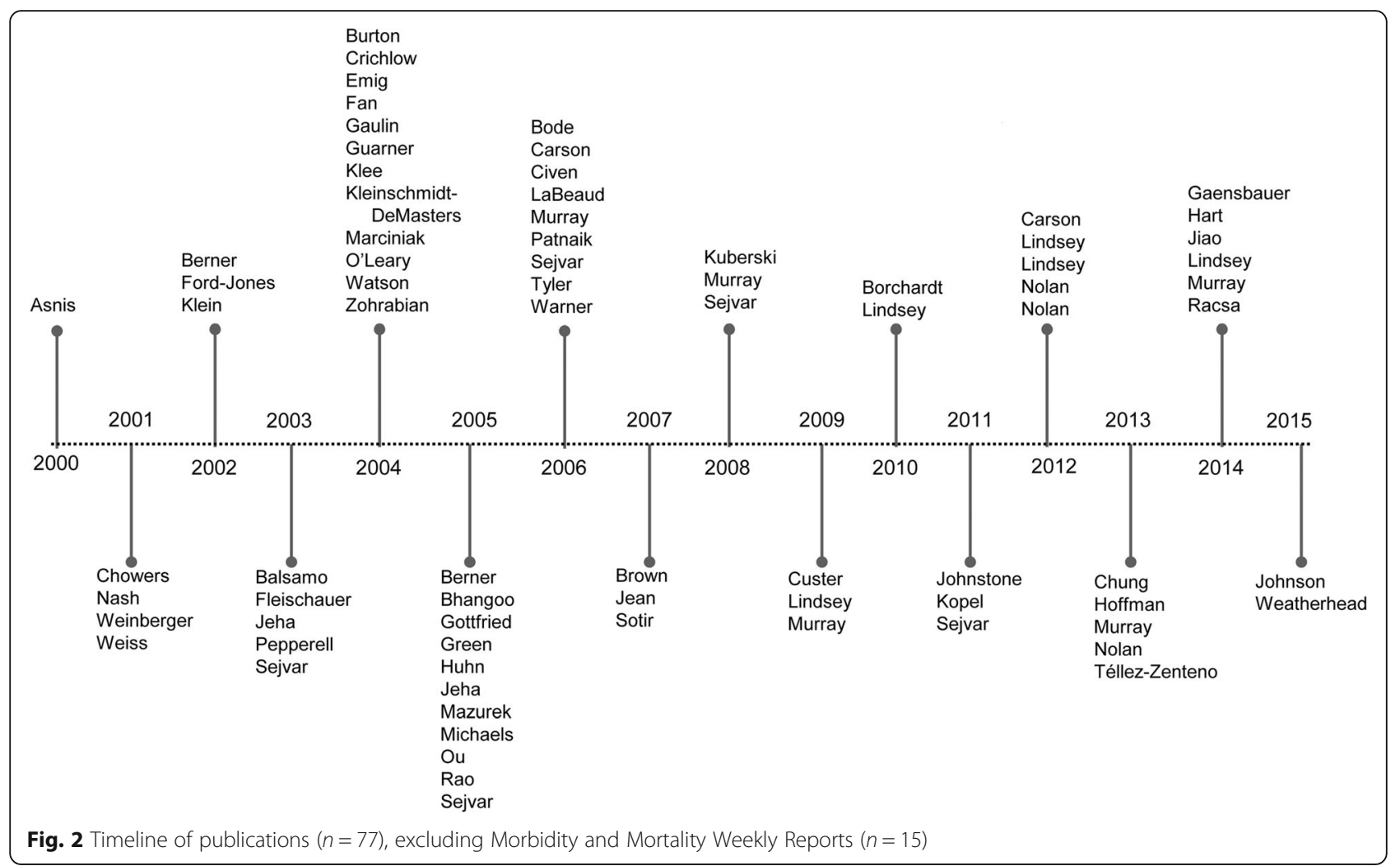

\section{AFP}

No data on in-hospital and long-term mortality were available. Acute mortality was as high as $50 \%$ with respiratory involvement [43].

\section{WNE}

In-hospital mortality for WNE ranged from 11 to $18 \%$ $[44,46]$, but reached up to $46 \%$ in the elderly ( $\geq 65$ years) [56], and $100 \%$ in combination with AFP [16]. One outlier was a case series in Montana of seven patients with WNME that reported $0 \%$ in-hospital mortality [28]. Acute mortality predominantly ranged from 3 to $18 \%[13,34]$, but reached up to $29 \%$ [50]. Long-term mortality was as high as $29 \%$ during the 4 years posthospitalization [50].

\section{WNM}

Patients with WNM experienced better survival than those with WNE. In-hospital mortality was < $2 \%$ [45] with most studies ( $n=4$ out of 5 ) reporting no deaths. Acute mortality was $<2 \%$ except in one Israeli study reporting $8 \%$ mortality [25]. Long-term mortality was $7 \%$ over 10 years of follow-up [48].

\section{WNF}

Studies reported no in-hospital $(n=4)$ or long-term mortality $(n=1)$. Acute mortality was between 0 and $1.2 \%[34,47,57]$.

\section{Risk factors associated with neuroinvasive disease}

Seventeen studies were summarized for clinical (Fig. 5; Additional file 1: Table S4) and sociodemographic risk factors (Additional file 1: Table S4) associated with developing WNND. Studies reported measures of association such as relative risks, odds ratios and hazard ratios.

\section{Clinical factors}

The most frequently studied clinical risk factors were diabetes, hypertension and cancer. There was inconsistency in whether these were statistically associated with WNND. Twelve studies examined diabetes, of which four found statistical significance [44, 58-60]. Bode reported the highest association, where the odds of developing WNE were four times greater in individuals with diabetes mellitus than individuals without, after controlling for age and alcohol abuse [44]. Hypertension was significant in five of ten studies [35, 49, 58-60], of which three studies came from the same Houston cohort. In the cohort, the odds of developing WNE were over three times greater in hypertensive patients than nonhypertensive patients after controlling for other comorbidities $[35,60]$ and the hazards were 2.4-times greater [49]. Cancer was significant in three of six studies $[40,58,60]$. The odds of developing WNE were three to eight times greater in individuals with cancer than those without $[40,58,60]$. Other clinical factors 


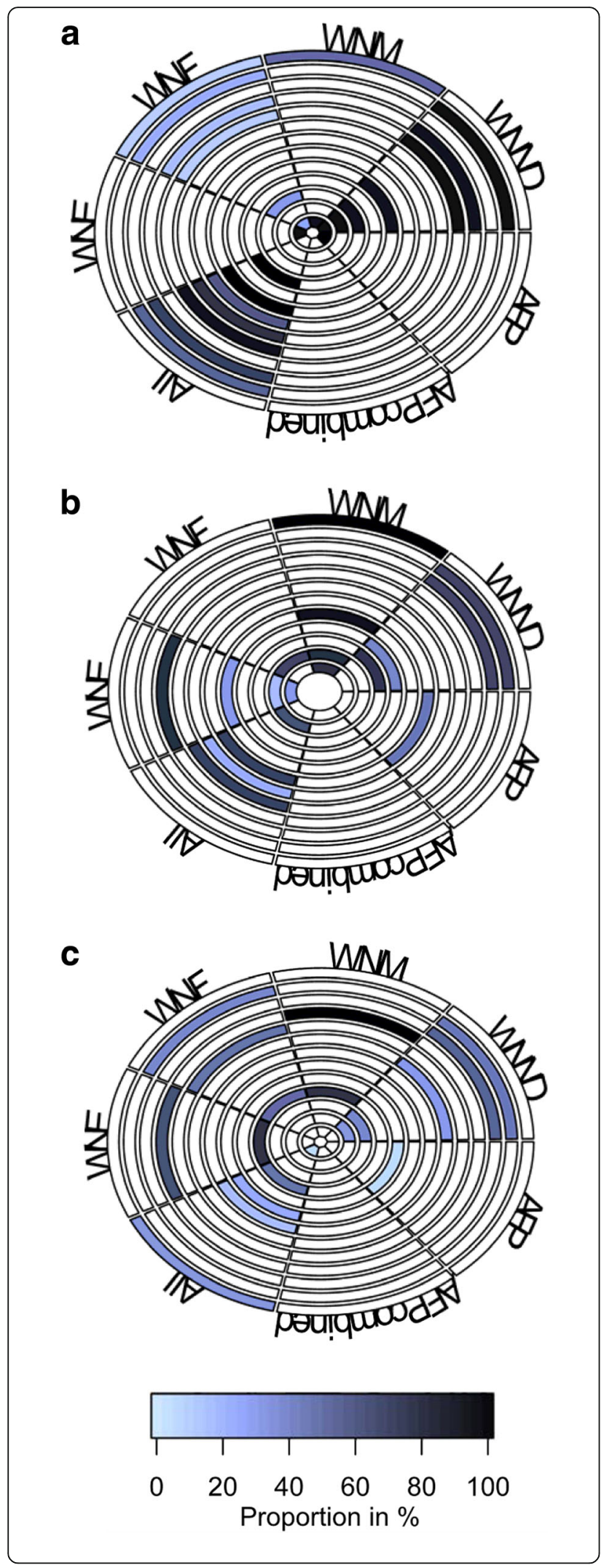

\begin{tabular}{|c|c|c|}
\hline \multicolumn{3}{|c|}{$\begin{array}{l}\text { Fig. } 3 \text { Rank-heat plots summarizing select hospitalization and } \\
\text { recovery outcomes data in patients with West Nile virus infection. } \\
\text { Proportion of patients hospitalized (a), patients discharged home (b) } \\
\text { and fully recovered (c) are represented by the shaded colour. Darker } \\
\text { shading represents a greater proportion of patients with outcomes } \\
\text { were reported. Each ring within the circle represents a study. Each } \\
\text { wedge represents a WNV syndrome. White sectors show studies } \\
\text { have no data on the syndrome/are not applicable }\end{array}$} \\
\hline $\begin{array}{l}\text { A. Rings from outside } \\
\text { in refer to: }\end{array}$ & $\begin{array}{l}\text { B. Rings from } \\
\text { outside in refer to: }\end{array}$ & $\begin{array}{l}\text { C. Rings from } \\
\text { outside in refer to: }\end{array}$ \\
\hline 1. Civen 2006 [63] & 1. Asnis 2000 [71] & 1. Klee 2004 [73] \\
\hline 2. Chung 2013 [66] & 2. Weiss 2001 [72] & 2. Gottfried 2005 [47] \\
\hline 3. Johnson 2015 [51] & 3. Emig 2004 [56] & 3. Jeha 2003 [74] \\
\hline 4. Lindsey 2009 [57] & 4. Rao 2005 [29] & 4. Sejvar 2003 [42] \\
\hline 5. Borchardt 2010 [61] & 5. Sejvar 2003 [42] & 5. Watson 2004 [39] \\
\hline 6. Murray 2014 [49] & 6. Pepperell 2003 [14] & 6. Hart 2014 [75] \\
\hline 7. Sotir 2007 [67] & 7. Sejvar 2005 [41] & 7. Pepperell 2003 [14] \\
\hline 8. Sejvar 2011 [68] & 8. Bhangoo 2005 [46] & $\begin{array}{l}\text { 8. Nolan 2012; } \\
\text { J Clin Psychol [76] }\end{array}$ \\
\hline 9. Gaensbauer 2014 [69] & 9. Burton 2004 [15] & 9. Sejvar 2005 [41] \\
\hline 10. Kuberski 2008 [55] & 10. Murray 2013 [6] & 10. Sejvar 2008 [77] \\
\hline 11. Jean 2007 [59] & 11. Bode 2006 [44] & 11. Racsa 2014 [32] \\
\hline $\begin{array}{l}\text { 12. Lindsey 2012; } \\
\text { Am J Trop Med Hyg [58] }\end{array}$ & 12. Tyler 2006 [45] & 12. Weiss 2001 [72] \\
\hline 13. Lindsey 2014 [70] & & 13. Hoffman 2013 [78] \\
\hline
\end{tabular}

may be associated with WNND including chronic renal disease, immunosuppression, human immunodeficiency virus (HIV), cardiovascular disease and liver disease.

\section{Sociodemographics}

There was consensus that increasing age was statistically associated with WNND. The odds ratios for patients aged 60-69 years compared to younger counterparts ranged between $2.1-10.5[6,35,58,59]$. Five of nine studies on gender found being male was a statistically significant risk factor. Their odds of developing WNND were 1.2-1.5-times greater than females [35, 59, 61]. Their odds for developing WNM specifically were 1.5times greater [58].

\section{Socioeconomics}

Four of six studies that included race found being non-white was a statistically significant risk factor. Lindsey et al. in the United States reported the highest association, where the odds of developing AFP/WNM were 3.6-times greater in non-whites than whites [58].

\section{Risk factors associated with mortality}

Nine studies were summarized for risk factors associated with all-cause mortality (Fig. 5; Additional file 1: Table S5). 


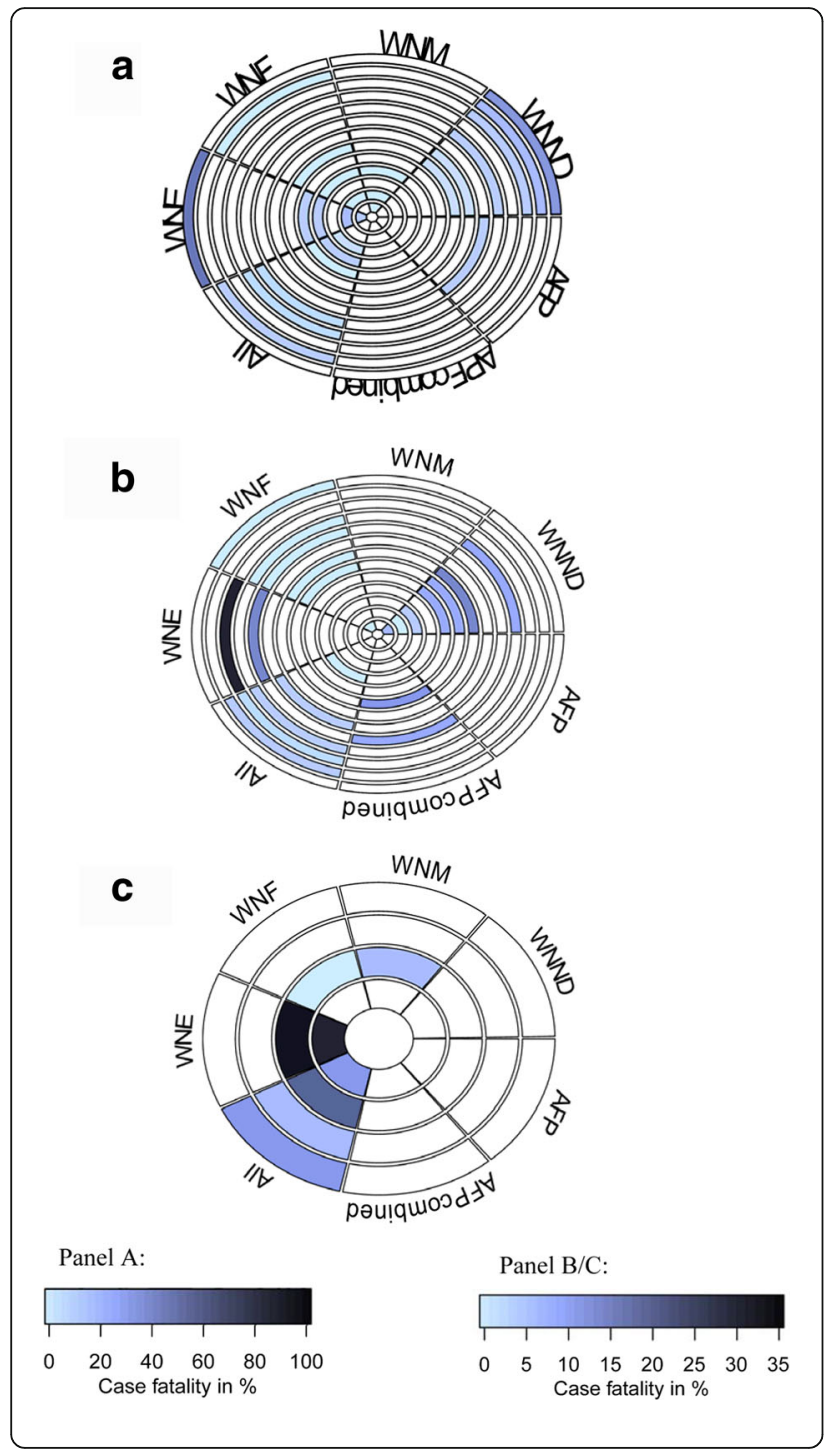

A. Rings from

outside in refer to:

1. Emig 2004 [56]

2. Gottfried 2005 [47]

3. Jeha 2003 [74]

4. Mazurek $2005[79$

5. Johnson 2015 [51]

6. Sejvar 2005 [41]

7. Téllez-Zenteno

2013 [19]

8. Racsa 2014 [32]

9. Bhangoo

2005 [46]

10. Murray 2006

Murray 2008 [35, 80]

11. Murray 2014 [49]

12. Bode 2006 [44]

13. Tyler 2006 [45]
B. Rings from outside

in refer to:

1. Sejvar 2011 [68]

2. Sotir 2007 [67]

3. Lindsey 2012; Vector

Borne Zoonotic Dis [50]

4. Chung 2013 [66]

5. Lindsey 2014 [70]

6. Murray 2013 [6]

7. Lindsey 2009 [57]

8. Lindsey 2010 [31]

9. Warner 2003,

Michaels $2005[52,53]$

10. Borchardt 2010 [61]

11. Nolan 2013 [54]

12. Gaensbauer 2014 [69]

13. Lindsey 2012;

Am J Trop Med Hyg [58]
C. Rings from outside in refer to:

1. Green 2005 [23]

2. Murray 2014 [49]

3. Weatherhead 2015 [48]

4. Lindsey 2012; Vector Borne Zoonotic Dis [50]

\section{Clinical factors}

Studies compared mortality in WNV patients with and without co-morbid conditions. Diabetes, hypertension and immunosuppression were the most frequently examined. Three of seven studies [23, 35, 37] found a significant association with diabetes, where the risk was increased up to five-fold. Two of five studies found hypertension to be a risk factor $[35,44]$ - the likelihood of death was five times greater compared to non-hypertensive patients [44]. Four of seven studies found immunosuppression to be a significant risk factor $[35,44,50,58]$ - the odds of death were three to four times greater compared to immunocompetent counterparts after controlling for age $[35,58]$. Chronic renal disease, cancer, cardiovascular disease and liver disease were other clinical factors potentially associated with mortality.

\section{Sociodemographics}

There was consensus that older age was statistically associated with the rate of death, doubling every 10 years [50]. The likelihood of death was three times greater in 5059 year olds compared to $0-39$ year olds [62]. The relative risk jumped to 30-times greater among 80-89 year olds [62]. One of two studies on sex found statistical significance, whereby being male was associated with a 1.5-times greater probability of death [62]. 


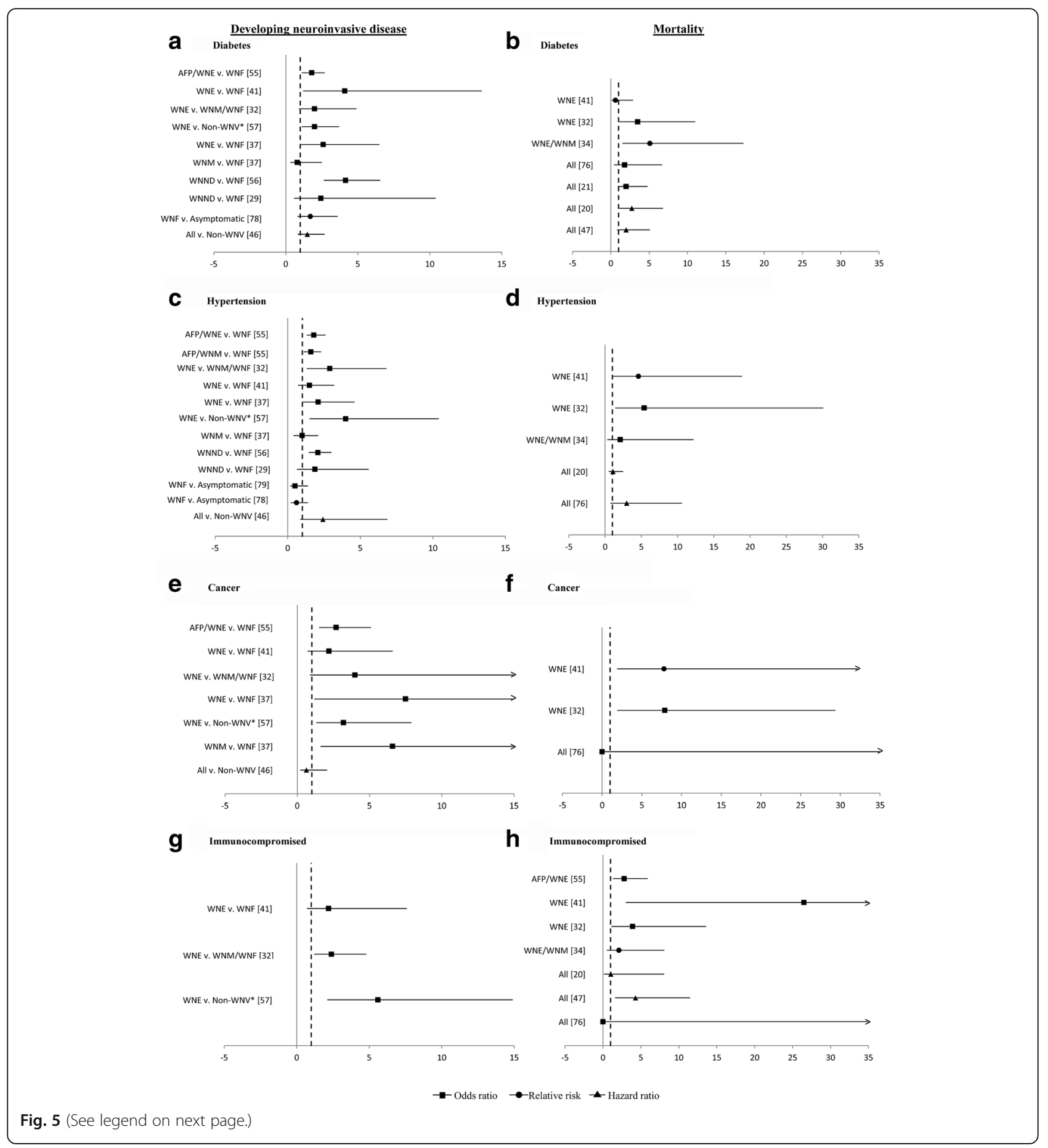




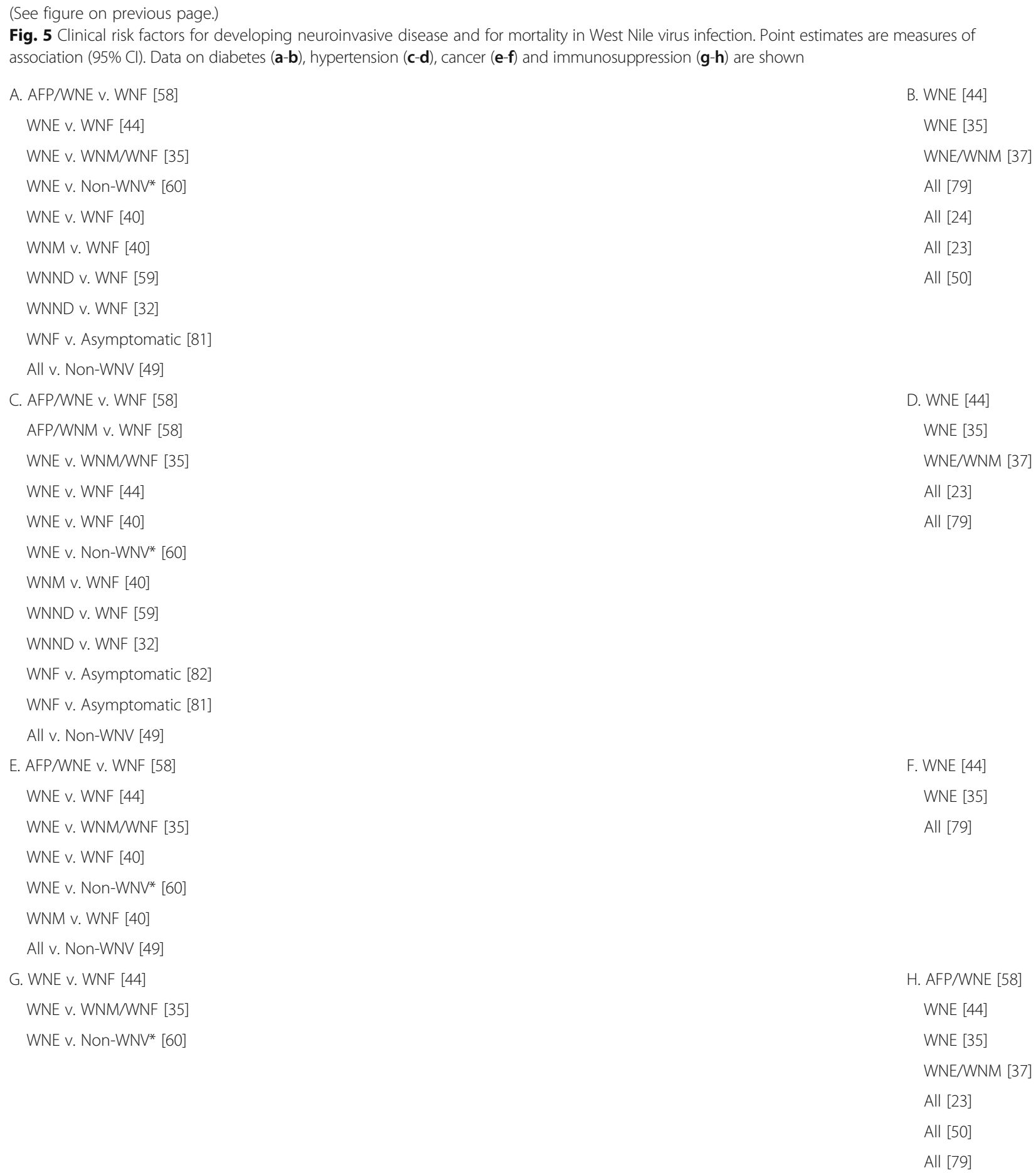

Fig. 5 Clinical risk factors for developing neuroinvasive disease and for mortality in West Nile virus infection. Point estimates are measures of association $(95 \% \mathrm{Cl})$. Data on diabetes $(\mathbf{a}-\mathbf{b})$, hypertension $(\mathbf{c}-\mathbf{d})$, cancer $(\mathbf{e}-\mathbf{f})$ and immunosuppression $(\mathbf{g}-\mathbf{h})$ are shown

A. AFP/WNE v. WNF [58]

WNE $v$. WNF [44]

B. WNE [44]

WNE v. WNM/WNF [35]

WNE [35]

WNE v. Non-WNV* [60]

WNE/WNM [37]

WNE v. WNF [40]

All [79]

WNM v. WNF [40]

All [24]

WNND v. WNF [59]

All [23]

WNND v. WNF [32]

All [50]

WNF v. Asymptomatic [81]

All v. Non-WNV [49]

C. AFP/WNE v. WNF [58]

AFP/WNM v. WNF [58]

D. WNE [44]

WNE $\vee$. WNMMNNF [35]

WNE [35]

WNE v. WNF [44]

WNE/WNM [37]

WNE v. WNF [40]

All [23]

WNE v. Non-WNV* [60]

All [79]

WNM v. WNF [40]

WNND v. WNF [59]

WNND v. WNF [32]

WNF v. Asymptomatic [82]

WNF v. Asymptomatic [81]

All v. Non-WNV [49]

E. AFP/WNE v. WNF [58]

F. WNE [44]

WNE $v$. WNF [44]

WNE [35]

WNE v. WNM/WNF [35]

All [79]

WNE v. WNF [40]

WNE v. Non-WNV* [60]

WNM v. WNF [40]

All v. Non-WNV [49]

G. WNE v. WNF [44]

H. AFP/WNE [58]

WNE v. WNM/WNF [35]

WNE [44]

WNE v. Non-WNV* [60]

WNE [35]

WNE/WNM [37]

All [23]

All [50]

All [79]

\section{Socioeconomics}

Being black was associated with a 12-times greater odds of death compared to non-Hispanic whites after controlling for age [35]. There was no statistical significance associated with being Hispanic [35].

\section{Discussion}

We summarized the peer-reviewed literature on epidemiologic and clinical parameters of WNV infection in North America. Parameters included hospitalization, recovery, mortality, risk factors for WNND and risk 
factors for mortality. Our review highlighted the heterogeneity in epidemiologic patterns across jurisdictions and outbreak seasons, even within North America. While there was consensus that age is a significant risk factor for neuroinvasive disease and death, the association of other sociodemographic and clinical factors was less definitive. Overall, patients with AFP or WNE fared worse than patients with WNM and WNF in terms of hospitalization and mortality. The proportion hospitalized, LOS, proportion discharged home and case-fatality ranged considerably among studies.

There was an overall lack of data specific to each WNV syndrome, particularly for AFP and WNME. This is despite that many of the syndromes behave distinctly. For instance, WNM is associated with better prognosis compared to other WNND syndromes. Also, there was a lack of data on the pediatric population. Only three studies [36, 57, 63] have this focus and noted markedly lower mortality in children compared to adults [57]. The incidence of WNND is also lower in children, as they are likely to remain asymptomatic or have milder disease [57].

We included 37 studies based on surveillance and monitoring programs on the national, state and local levels. Systems included passive surveillance (e.g., ArboNET) and active surveillance (e.g., sentinel hospitals). Estimates from these population-based systems should have greater external validity than cohorts and case series where patients are recruited from small catchment areas. However, such studies are prone to differential surveillance bias, given patients with WNND are more likely to be detected than patients with WNF. The latter group may not seek medical care for mild symptoms or may not be correctly diagnosed when only presenting with flu-like symptoms, resulting in underreporting of mild to moderate WNV illness. Thus, ensuring effective surveillance programs in regions with endemic WNV remains important, especially since WNV outbreaks tend to be unpredictable by year.

In addition, case-fatality estimates calculated using WNV-related illness in the denominator may be underestimated due to underreporting of non-severe WNV cases. Similarly, case-fatality estimates would be affected in studies that only include confirmed cases in the denominator of total infected cases, compared to studies that include both confirmed and probable cases. Other challenges to population-based surveillance data include identifying WNV cases, balancing sensitivity and specificity, especially from health administrative databases. When using inpatient hospital discharge data alone, WNV had a sensitivity of 77\%, much lower than other reportable diseases such as Shigellosis (100\%) and Salmonellosis (91\%) [64].
Our review results are contingent on the validity and data caveats of the studies summarized. Several studies $(n=19)$ had sample sizes under 25 , and thus may have limited external validity. Among mortality studies, only five reported deaths attributable to WNV. By including mortality from all causes, the remaining studies may be overestimating WNV case fatalities. Other issues include potential misclassification of patients whose outcomes are ascertained from death certificates. Among studies that compared patients with WNND and WNF, adjusting for age and sex was not done for mortality outcomes. This can be problematic since patients with WNF tend to be younger and healthier [30]. Overall, few risk factor studies $(n=10)$ adjusted for confounding. The most common adjustments were age and select comorbid conditions. Unadjusted estimates and residual confounding may explain the discordant results.

The strength of this review lies in the systematic search of four bibliographic databases and independent screening by two reviewers. We did not search conference proceedings or other grey literature, leaving the review prone to publication bias. We were unable to assess the extent of this bias given the qualitative nature of the work. Further, we did not assess study quality as per scoping review recommendations [8, 65]. Quality assessments, however, can inform the utility of epidemiologic data, but should be undertaken in reviews with a more defined scope of research. We propose a systematic review with critical appraisal be conducted on studies of risk factors for WNV-illness and mortality, with the potential for meta-analysis, particularly to estimate the magnitude of age and sex as risk factors for neuroinvasive disease and mortality.

\section{Conclusion}

In conclusion, our review highlights the heterogeneity among reporting clinical WNV syndromes and epidemiologic parameters of WNV-related illness, mostly summarized from studies on outbreaks in North America. Future research on risk factors and the economic burden of WNV and vector-borne diseases can build on existing evidence summarized in this review, not only to support endemic mosquito-borne diseases, but also to strengthen research on emerging arboviruses with similar clinical manifestations (e.g., Zika, chikungunya). Though widely established across the USA and Canada, fluctuating patterns of WNV incidence by year introduces challenges to evaluating costs and recommendations for policy on the cost-effectiveness of interventions (e.g., vector management programs, adulticiding, and WNV vaccine development). A greater understanding of WNV disease burden is warranted for guiding clinical care and evidence-informed policy-making. 


\section{Additional files}

Additional file 1: Appendix 1. Tables S2-S5. Appendix 1. Search strategy in Ovid MEDLINE(R) In-Process \& Other Non-Indexed Citations and Ovid MEDLINE(R) 1946 to Present. Table S2. Summary of index hospitalization, discharge home and full recovery in patients with West Nile virus infection. Table S3. Summary of mortality data in patients with West Nile virus infection. Table S4. Risk factors for developing West Nile neuroinvasive disease. Table S5. Risk factors for mortality in patients with West Nile virus infection. (DOCX $148 \mathrm{~kb}$ )

Additional file 2: Table S1. Characteristics of included studies ( $n=92)$ (XLSX $28 \mathrm{~kb})$

\section{Abbreviations}

AFP: Acute flaccid paralysis; HIV: Human immunodeficiency virus; LOS: Length of stay; WNE: West Nile encephalitis; WNF: West Nile fever; WNM: West Nile meningitis; WNME: West Nile meningoencephalitis: WNND: West Nile neuroinvasive disease; WNV: West Nile virus

\section{Acknowledgements}

We thank Susan Massarella, library information specialist at Public Health Ontario, for developing and running the search strategies. We also thank Dr. Andrea Tricco and her team for their input on data visualization and $\mathrm{R}$ code for generating graphics.

\section{Funding}

This research was funded by a Canadian Institutes of Health Research Operating Grant (MOP: 133,571), part of a larger study on the cost-effectiveness of West Nile virus intervention strategies.

\section{Availability of data and materials}

Data sharing not applicable to this article as no datasets were generated or analysed during the current study.

\section{Authors' contributions}

MY performed literature review, data extraction, data synthesis, wrote the manuscript, and managed revisions at all stages. ES performed the literature review, data extraction, data synthesis, and contributed to writing and editing the manuscript. BS conceived the study, supervised the project, and commented on the manuscript development at all stages. MPN provided editing to the manuscript and reviewed it for content relevance. All authors read and approved the final manuscript.

\section{Ethics approval and consent to participate}

This study was approved by the Public Health Ontario Ethics Review Board.

\section{Consent for publication}

Not applicable.

\section{Competing interests}

The authors declare that they have no competing interests.

\section{Publisher's Note}

Springer Nature remains neutral with regard to jurisdictional claims in published maps and institutional affiliations.

\section{Received: 16 March 2017 Accepted: 25 July 2017}

Published online: 06 September 2017

\section{References}

1. Harrigan RJ, Thomassen HA, Buermann W, Smith TB. A continental risk assessment of West Nile virus under climate change. Glob Chang Biol. 2014:20:2417-25.

2. Debiasi RL, Tyler KL. West Nile virus meningoencephalitis. Nat Clin Pract Neurol. 2006:2:264-75.

3. Staples JE, Shankar MB, Sejvar JJ, Meltzer MI, Fischer M. Initial and long-term costs of patients hospitalized with West Nile virus disease. Am J Trop Med Hyg. 2014;90:402-9.
4. Barber LM, Schleier JJ, Peterson RKD. Economic cost analysis of West Nile virus outbreak, Sacramento County, California, USA, 2005. Emerg Infect Dis. 2010;16:480-6.

5. Zohrabian A, Meltzer MI, Ratard R, Billah K, Molinari NA, Roy K, et al. West Nile virus economic impact, Louisiana, 2002. Emerg Infect Dis. 2004;10:1736-44.

6. Murray KO, Ruktanonchai D, Hesalroad D, Fonken E, Nolan MS. West Nile virus, Texas, USA, 2012. Emerg Infect Dis. 2013;19:1836-8.

7. Patel $H$, Sander B, Nelder MP. Long-term sequelae of West Nile virus-related illness: a systematic review. Lancet Infect Dis. 2015;15:951-9.

8. Peters MDJ, Godfrey CM, Khalil H, Mclnerney P, Parker D, Soares CB. Guidance for conducting systematic scoping reviews. Int J Evid Based Healthc. 2015;13:141-6.

9. Bakonyi T, Ivanics E, Erdélyi K, Ursu K, Ferenczi E, Weissenböck H, Nowotny $\mathrm{N}$. Lineage 1 and 2 strains of encephalitic West Nile virus, central Europe. Emerg Infect Dis. 2006;12(4):618-23. PubMed PMID: 16704810; PubMed Central PMCID: PMC3294705. https://www.ncbi.nlm.nih.gov/pmc/articles/ PMC3294705/

10. Calistri P, Giovannini A, Hubalek Z, lonescu A, Monaco F, Savini G, Lelli R. Epidemiology of West Nile in Europe and in the mediterranean basin. Open Virol J. 2010:4:29-37. PubMed PMID: 20517490; PubMed Central PMCID: PMC2878979. doi:10.2174/1874357901004020029.

11. Giladi M, Metzkor-Cotter E, Martin DA, Siegman-lgra Y, Korczyn AD, Rosso R, et al. West Nile encephalitis in Israel. In: the New York connection, Emerg. Infect. Dis, vol. 7; 1999. p. 659-61.

12. Hernández-Triana $L M$, Jeffries $C L$, Mansfield $K L$, Carnell G, Fooks $A R$, Johnson N. Emergence of West Nile Virus Lineage 2 in Europe: A Review on the Introduction and Spread of a Mosquito-Borne Disease. Front Public Health [Internet]. 2014;2:271. Available from: http://journal.frontiersin.org/article/10. 3389/fpubh.2014.00271

13. Ford-Jones EL, Fearon M, Leber C, Dwight P, Myszak M, Cole B, et al. Human surveillance for West Nile virus infection in Ontario in 2000. CMAJ. 2002;166:29-35

14. Pepperell C, Rau N, Krajden S, Kern R, Humar A, Mederski B, et al. West Nile virus infection in 2002: morbidity and mortality among patients admitted to hospital in southcentral Ontario. CMAJ. 2003;168:1399-405.

15. Burton JM, Kern RZ, Halliday W, Mikulis D, Brunton J, Fearon M, et al. Neurological manifestations of West Nile virus infection. Can J Neurol Sci. 2004;31:185-93.

16. Fan E, Needham DM, Brunton J, Kern RZ, Stewart TE. West Nile virus infection in the intensive care unit: a case series and literature review. Can Respir J. 2004;11:354-8.

17. Gaulin C, Couillard M, Pilon PA, Tremblay M, Lambert L, Fradet MD, et al Assessment of surveillance of human West Nile virus infection in Quebec 2003. Can Commun Dis Rep. 2004;30:97-104.

18. Johnstone J, Hanna SE, Nicolle LE, Drebot MA, Neupane B, Mahony JB, et al. Prognosis of West Nile virus associated acute flaccid paralysis: a case series. J Med Case Rep. 2011;5:395.

19. Téllez-Zenteno JF, Hunter G, Hernández-Ronquillo L, Haghir E. Neuroinvasive West Nile virus disease in Canada. The Saskatchewan experience. Can. Neurol Sci. 2013:40:580-4

20. Jiao L, Main C. A brief report of West Nile Virus neuroinvasive disease in the summer of 2012 in Hamilton, Ontario. Can J Infect Dis Med Microbiol. 2014;25:24-6.

21. Berner YN, Lang R, Chowers MY. Outcome of West Nile fever in older adults. J Am Geriatr Soc. 2002;50:1844-6.

22. Weinberger M, Pitlik SD, Gandacu D, Lang R, Nassar F, Ben David D, et al. West Nile fever outbreak, Israel, 2000: Epidemiologic aspects. Emerg Infect Dis. 2001;7:686-91.

23. Green MS, Weinberger M, Ben-Ezer J, Bin H, Mendelson E, Ganclacu D, et al. Long-term death rates, West Nile virus epidemic, Israel 2000. Emerg Infect Dis. 2005;11:1754-7.

24. Chowers MY, Lang R, Nassar F, Ben-David D, Giladi M, Rubinshtein E, Itzhaki A, Mishal J, Siegman-Igra Y, Kitzes R, Pick N, Landau Z, Wolf D, Bin H, Mendelson E, Pitlik SD, Weinberger M. Clinical characteristics of the West Nile fever outbreak, Israel, 2000. Emerg Infect Dis. 2001:7(4):675-8. PubMed PMID: 11585531; PubMed Central PMCID: PMC2631759. https://www.ncbi. nlm.nih.gov/pmc/articles/PMC2631759/.

25. Kopel E, Amitai Z, Bin H, Shulman LM, Mendelson E, Sheffer R. Surveillance of West Nile virus disease, Tel Aviv district, Israel, 2005 to 2010. Eur Commun Dis BullSweden. 2011;16 
26. Klein C, Kimiagar I, Pollak L, Gandelman-Marton R, Itzhaki A, Milo R, et al. Neurological features of West Nile virus infection during the 2000 outbreak in a regional hospital in Israel. J Neurol SciNetherlands. 2002;200:63-6.

27. Berner Y, Feldman J, Spigel D, Chowers M, Finckeltov B. Rehabilitation of West Nile Fever (WNF) encephalitis in elderly. Arch Gerontol Geriatr. 2005:41:15-21.

28. Crichlow R, Bailey J, Gardner C. Cerebrospinal fluid neutrophilic pleocytosis in hospitalized West Nile virus patients. J Am Board Fam Pract. 2004;17:470-2.

29. Rao N, Char D, Gnatz S. Rehabilitation outcomes of 5 patients with severe West Nile virus infection: A case series. Arch Phys Med Rehabil. 2005;86:449-52.

30. Sejvar JJ. The long-term outcomes of human West Nile virus infection. Clin Infect Dis. 2007:44:1617-24.

31. Lindsey NP, Staples JE, Lehman JA, Fischer M. Surveillance for human West Nile virus disease - United States, 1999-2008. MMWR Surveill Summ. 2010;59:1-17.

32. Racsa L, Gander R, Chung W, Southern P, Le J, Beal S, et al. Clinical features of West Nile virus epidemic in Dallas, Texas, 2012. Diagn Microbiol Infect Dis. 2014;78:132-6.

33. Marciniak C, Sorosky S, Hynes C. Acute flaccid paralysis associated with West Nile virus: Motor and functional improvement in 4 patients. Arch Phys Med Rehabil. 2004;85:1933-8.

34. Huhn GD, Austin C, Langkop C, Kelly K, Lucht R, Lampman R, et al. The emergence of west nile virus during a large outbreak in Illinois in 2002. Am J Trop Med Hyg. 2005;72:768-76.

35. Murray K, Baraniuk S, Resnick M, Arafat R, Kilborn C, Cain K, et al. Risk factors for encephalitis and death from West Nile virus infection. Epidemiol Infect. 2006;134:1325-32.

36. LaBeaud AD, Lisgaris MV, King CH, Mandalakas AM. Pediatric West Nile virus infection: neurologic disease presentations during the 2002 epidemic in Cuyahoga County, Ohio. Pediatr Infect Dis J. 2006;25:751-3.

37. Nash D, Mostashari F, Fine A, Miller J, O'Leary D, Murray K, et al. The outbreak of West Nile virus infection in the New York City area in 1999. N Engl J Med. 2001;344:1807-14

38. Carson PJ, Konewko P, Wold KS, Mariani P, Goli S, Bergloff P, et al. Longterm clinical and neuropsychological outcomes of West Nile virus infection. Clin Infect Dis. 2006;43:723-30.

39. Watson JT, Pertel PE, Jones RC, Siston AM, Paul WS, Austin CC, et al. Clinical characteristics and functional outcomes of West Nile Fever. Ann Intern MedUnited States. 2004;141:360-5.

40. Patnaik JL, Harmon H, Vogt RL. Follow-up of 2003 human West Nile virus infections, Denver, Colorado. Emerg Infect Dis. 2006;12:1129-31.

41. Sejvar JJ, Bode AV, Marfin AA, Campbell GL, Ewing D, Mazowiecki M, et al. West Nile virus-associated flaccid paralysis. Emerg Infect Dis. 2005;11:1021-7.

42. Sejvar JJ, Haddad MB, Tierney BC, Campbell GL, Marfin AA, Van Gerpen JA, et al. Neurologic manifestations and outcome of West Nile virus infection. JAMA. 2003;290:511-5.

43. Sejvar JJ, Bode AV, Marfin AA, Campbell GL, Pape J, Biggerstaff BJ, et al. West Nile Virus-associated flaccid paralysis outcome. Emerg Infect Dis. 2006;12:514-6.

44. Bode AV, Sejvar JJ, Pape WJ, Campbell GL, Marfin AA. West Nile virus disease: a descriptive study of 228 patients hospitalized in a 4-county region of Colorado in 2003. Clin Infect Dis. 2006;42:1234-40.

45. Tyler KL, Pape J, Goody RJ, Corkill M, Kleinschmidt-DeMasters BK. CSF findings in 250 patients with serologically confirmed West Nile virus meningitis and encephalitis. Neurology. 2006;66:361-5.

46. Bhangoo S, Chua R, Hammond C, Kimmel Z, Semenov I, Videnovic A, et al. Focal neurological injury caused by West Nile virus infection may occur independent of patient age and premorbid health. J Neurol Sci. 2005;234:93-8.

47. Gottfried K, Quinn R, Jones T. Clinical description and follow-up investigation of human West Nile virus cases. South Med J. 2005;98:603-6.

48. Weatherhead JE, Miller VE, Garcia MN, Hasbun R, Salazar L, Dimachkie MM, et al. Long-term neurological outcomes in West Nile virus-infected patients: an observational study. Am J Trop Med Hyg. 2015;92:1006-12.

49. Murray KO, Garcia MN, Rahbar MH, Martinez D, Khuwaja SA, Arafat RR, et al. Survival analysis, long-term outcomes, and percentage of recovery up to 8 years post-infection among the Houston West Nile virus cohort. PLoS One. 2014;9

50. Lindsey NP, Sejvar JJ, Bode AV, Pape WJ, Campbell GL. Delayed mortality in a cohort of persons hospitalized with West Nile virus disease in Colorado in 2003. Vector Borne Zoonotic Dis. United States. 2012;12:230-5.
51. Johnson MG, Adams J, McDonald-Hamm C, Wendelboe A, Bradley KK. Seasonality and survival associated with three outbreak seasons of West Nile virus disease in Oklahoma-2003, 2007, and 2012. J Med Virol United States. 2015;87:1633-40.

52. Warner RD, Kimbrough RC, Alexander JL, Rush Pierce J, Ward T, Martinelli LP. Human West Nile Virus Neuroinvasive Disease in Texas, 2003 Epidemic: Regional Differences. Ann Epidemiol. 2006;16:749-55.

53. Michaels SR, Balsamo GA, Kukreja M, Anderson C, Straif-Bourgeois S, Talati G, et al. Surveillance for West Nile virus cases in Louisiana 2001-2004. J La State Med Soc. 2005;157:269-72.

54. Nolan MS, Schuermann J, Murray KO. West Nile virus infection among humans, Texas, USA, 2002-2011. Emerg Infect Dis. 2013;19:137-9.

55. Kuberski T, Brown C, Robinson L. Clinical observations on West Nile virus infections. Infect Med. 2008;25:430-4.

56. Emig M, Apple DJ. Severe West Nile virus disease in healthy adults. Clin Infect Dis. 2004;38:289-92.

57. Lindsey NP, Hayes EB, Staples JE, Fischer M. West Nile virus disease in children, United States, 1999-2007. Pediatrics. 2009;123:e1084-9.

58. Lindsey NP, Staples JE, Lehman JA, Fischer M. Medical risk factors for severe West Nile Virus disease, United States, 2008-2010. Am J Trop Med Hyg. 2012:87:179-84

59. Jean CM, Honarmand S, Louie JK, Glaser CA. Risk factors for West Nile virus neuroinvasive disease, California, 2005. Emerg Infect Dis. 2007;13:1918-20.

60. Murray KO, Koers E, Baraniuk S, Herrington E, Carter H, Sierra M, et al. Risk factors for encephalitis from west nile virus: A matched case-control study using hospitalized controls. Zoonoses Public Health. 2009;56:370-5.

61. Borchardt SM, Feist MA, Miller T, Lo TS. Epidemiology of West Nile virus in the highly epidemic state of North Dakota, 2002-2007. Public Health Rep. 2010;125:246-9.

62. O'Leary DR, Marfin AA, Montgomery SP, Kipp AM, Lehman JA, Biggerstaff BJ, et al. The epidemic of West Nile virus in the United States, 2002. Vector Borne Zoonotic Dis. 2004:4:61-70.

63. Civen R, Villacorte F, Robles DT, Dassey DE, Croker C, Borenstein L, et al. West Nile virus infection in the pediatric population. Pediatr Infect Dis J. 2006;25:75-8

64. Boehmer TK, Patnaik JL, Burnite SJ, Ghosh TS, Gershman K, Vogt RL. Use of hospital discharge data to evaluate notifiable disease reporting to Colorado's Electronic Disease Reporting System. Public Health Rep. 126:100-6.

65. Arksey H, O'Malley L. Scoping studies: towards a methodological framework. Int J Soc Res Methodol. 2005;8:19-32. doi:10.1080/ 1364557032000119616.

66. Chung WM, Buseman CM, Joyner SN, Hughes SM, Fomby TB, Luby JP, et al. The 2012 West Nile encephalitis epidemic in Dallas, Texas. JAMA. 2013; 310:297-307.

67. Sotir MJ, Glaser LC, Fox PE, Doering M, Geske DA, Warshauer DM, et al. Endemic human mosquito-borne disease in Wisconsin residents, 2002-2006. WMJ. 2007;106:185-90.

68. Sejvar JJ, Lindsey NP, Campbell GL. Primary causes of death in reported cases of fatal West Nile Fever, United States, 2002-2006. Vector Borne Zoonotic Dis. 2011;11:161-4

69. Gaensbauer JT, Lindsey NP, Messacar K, Staples JE, Fischer M. Neuroinvasive arboviral disease in the United States: 2003 to 2012. Pediatrics. 2014;134:e642-50.

70. Lindsey NP, Staples JE, Delorey MJ, Fischer M. Lack of evidence of increased west nile virus disease severity in the United States in 2012. Am J Trop Med Hyg. 2014;90:163-8.

71. Asnis DS, Conetta R, Teixeira AA, Waldman G, Sampson BA. The West Nile Virus outbreak of 1999 in New York: the Flushing Hospital experience. Clin Infect Dis. 2000;30:413-8.

72. Weiss D, Carr D, Kellachan J, Tan C, Phillips M, Bresnitz E, et al. Clinical findings of West Nile virus infection in hospitalized patients, New York and New Jersey, 2000. Emerg Infect Dis. 2001;7:654-8.

73. Klee AL, Maidin B, Edwin B, Poshni I, Mostashari F, Fine A, et al. Longterm prognosis for clinical West Nile virus infection. Emerg Infect Dis. 2004;10:1405-11.

74. Jeha LE, Sila CA, Lederman RJ, Prayson RA, Isada CM, Gordon SM. West Nile virus infection: a new acute paralytic illness. Neurology. 2003;61:55-9.

75. Hart J, Tillman G, Kraut MA, Chiang H-S, Strain JF, Li Y, et al. West Nile virus neuroinvasive disease: neurological manifestations and prospective longitudinal outcomes. BMC Infect Dis. 2014;14:248.

76. Nolan MS, Hause AM, Murray KO. Findings of Long-Term Depression up to 8 Years Post Infection From West Nile Virus. J Clin Psychol. 2012;68:801-8. 
77. Sejvar JJ, Curns AT, Welburg L, Jones JF, Lundgren LM, Capuron L, et al. Neurocognitive and functional outcomes in persons recovering from West Nile virus illness. J Neuropsychol. 2008;2:477-99.

78. Hoffman JE, Paschal KA. Functional outcomes of adult patients with West Nile virus admitted to a rehabilitation hospital. J Geriatr Phys Ther. 2013;36:55-62.

79. Mazurek JM, Winpisinger K, Mattson BJ, Duffy R, Moolenaar RL. The epidemiology and early clinical features of West Nile virus infection. Am J Emerg Med. 2005;23:536-43.

80. Murray KO, Baraniuk S, Resnick M, Arafat R, Kilborn C, Shallenberger R, et al. Clinical investigation of hospitalized human cases of West Nile virus infection in Houston, Texas, 2002-2004. Vector Borne Zoonotic Dis. 2008:8:167-74.

81. Brown JA, Factor DL, Tkachenko N, Templeton SM, Crall ND, Pape WJ, et al. West Nile viremic blood donors and risk factors for subsequent West Nile fever. Vector Borne Zoonotic Dis. 2007;7:479-88.

82. Custer B, Kamel H, Kiely NE, Murphy EL, Busch MP. Associations between West Nile virus infection and symptoms reported by blood donors identified through nucleic acid test screening. Transfusion. 2009;49:278-88.

Submit your next manuscript to BioMed Central and we will help you at every step:

- We accept pre-submission inquiries

- Our selector tool helps you to find the most relevant journal

- We provide round the clock customer support

- Convenient online submission

- Thorough peer review

- Inclusion in PubMed and all major indexing services

- Maximum visibility for your research

Submit your manuscript at www.biomedcentral.com/submit
Biomed Central 